\title{
Fra redaktionen
}

Byerne er kommet på verdenskortet som helt særlige internationale aktører. De kan ikke løse konflikten i Syrien eller afværge Brexit, men de kan være med til at adressere globale spørgsmål med konkrete handlinger på klimaområdet i samarbejde med andre byer eller byde ind med innovative tiltag på integrations- og fattigdomsproblematikker.

Om 35 år vil tre mia. mennesker bo i byer. Derfor er målet om bæredygtige byudvikling blevet til ét af FN's 17 verdensmål frem mod 2030. Den eksplosive globale urbanisering vil skabe et massivt behov for bæredygtige byløsninger: økonomisk vækst, vand, energi, transport, boligforhold, klimatilpasning. Klimaaftalen fra Paris lægger op til et tæt parløb mellem offentlige og private aktører om mobilisering af ressourcer til udvalgte fokusområder og tiltænker byerne en særlig rolle i gennemførelsen af aftalen.

For Danmark giver det nye muligheder for at samtænke udviklingssamarbejde og økonomisk diplomati på områder, hvor vi har særlige erfaringer og styrker. Det Udenrigspolitiske Selskab afholder derfor sammen med Realdania en konference om bæredygtighed og den globale urbanisering for danske beslutningstager og aktører på området. Det har givet inspiration til dette nummer af Udenrigs. Blandt andet har vi et interview med Brookings Institute's Bruce J. Katz, som beskriver byernes udvikling i USA som en kraft, der vil ændre USA's samfundsmæssige landskab så vidtgående, at man kan tale om 'metropolernes revolution'.

Briternes folkeafstemning, der faldt ud til fordel for at forlade EU, var så skelsættende en begivenhed, at vi i 'Baggrund' bringer et minitema om Brexit, bestående af tre artikler om UK før og efter Brexit; om Brexits konsekvenser for bl.a. forholdet mellem England, Skotland og EU; og endelig om Brexits betydning for det vestlige Balkan.

Sidste artikel i 'Baggrund' er Ivan Krastev og Mark Leonards artikel fra 2014 'Den nye europæiske uorden', som vi mener er så nyskabende i sit syn på forholdet EURusland, at den bør bringes ud til et større dansk publikum.

Endelig anmeldes Anders Fogh Rasmussens bog om viljen til at lede samt bøger om magtbalance, værdier og samarbejde, om danske FN-soldaters (utilstrækkelige) mandat og om arven efter osmannerne.

God læselyst!

Redaktionen 